\title{
SINDICALISMO DE ESTADO: CONTROLE E REPRESSÃO NA ERA VARGAS (1930-1935)
}

\author{
Fábio Campinho*
}

\begin{abstract}
RESUMO
A análise busca, através do estudo dos primeiros anos do governo Vargas, enfocar o processo de construção de um modelo de organização sindical pautado na noção de sindicato único, na necessidade de controle estatal sobre os sindicatos e em concepções corporativas das relações entre capital e trabalho. Além disso, mostra-se como essa nova forma jurídico-política dos sindicatos, que vai se consolidando, ao longo da década de 1930, está longe de ser o ponto originário do sindicalismo no Brasil. Ao contrário, os diversos diplomas que implementavam os sindicatos de tipo corporativo, tiveram que se contrapor, muitas vezes amparados pela repressão Estatal, à tradição de organizações operárias livres, desvinculadas do controle estatal, herdadas da República Velha.

Palavras-Chave: sindicalismo; corporativismo; controle; Estado; Getúlio Vargas.
\end{abstract}

Sumário: 1 INTRODUÇÃO; 2 SINDICALISMO E REPÚBLICA VELHA; 3 TRANSIÇÃO PARA O SINDICALISMO CORPORATIVO; 4 A LEI DE SINDICALIZAÇÃO DE 1931; 5 A CONSTITUIÇÃO DE 1934 E O DECRETO 24.694; 6 CONCLUSÃO; 7 REFERÊNCIAS.

* Mestre em Direito - UFPR. Endereço eletrônico: fabiocampinho@yahoo.com.br 


\section{INTRODUÇÃO}

Há uma razão específica para a preocupação em retomar um tema tão exaustivamente abordado na historiografia brasileira, como o sindicalismo na era Vargas. Trata-se de um imperativo do presente, de uma demanda jurídico-política contemporânea, ou seja: a possibilidade de uma reforma da estrutura sindical brasileira.

Em 2003, foi organizado pelo MTE (Ministério do Trabalho e Emprego) o Fórum Nacional do Trabalho, de composição tripartite. Com base nas discussões e consensos dele retirados, posteriormente transformados na PEC no 369/2005 e no Anteprojeto de Lei de Relações Sindicais, pretendia-se instituir uma nova regulação para o sindicalismo brasileiro. No entanto, a crise política instaurada no Palácio do Planalto e no Congresso Nacional, a partir de meados de 2005, travou o andamento da Reforma Sindical. O tema parecia morto, mas ressurgiu com a reeleição de Lula e com a recomposição da base de apoio do governo no Congresso.

Apesar de não ser o objetivo deste artigo debater o conteúdo da Reforma, parece que sua proximidade é um importante móvel no intuito de uma melhor compreensão da história do sindicalismo pátrio, tanto no aspecto concernente à dinâmica do movimento operário, quanto no que se refere às configurações institucionais.

A opção pelo período Vargas justifica-se por marcar "o fim de um ciclo e o início de outro na economia brasileira: o fim da hegemonia agrário-exportadora e o início da predominância da estrutura produtiva de base urbano-industrial"1 ${ }^{1}$ sendo que, no que se refere à organização sindical, representa a consolidação de um modelo que irá sobreviver com pujança à transição democrática de 1945 à 1964, à ditadura militar e, em certa medida, da reabertura política na década de 1980 até os dias atuais. ${ }^{2}$

${ }^{1}$ (OLIVEIRA, F. Crítica à razão dualista. São Paulo: Boitempo, 2003, p. 35). Refere-se aqui ao período pós-1930.

${ }^{2}$ Não se quer com isso ignorar todas as modificações por que passou a legislação sindical, 
Porém, não se pretende aqui trabalhar toda a era Vargas. Trata-se apenas de uma análise específica do processo de construção do sindicalismo oficial, ou seja, de como se deu a transição da regulação sindical liberal, típica da República Velha, para o sindicato tutelado pelo Estado, nos primeiros anos após a revolução de 1930. Abordase, portanto, com intuito comparativo, os diplomas legais que regiam o sindicalismo no início do século e as formas de atuação operárias. Após, identificam-se as leis que introduziram o sindicalismo na década de 30, em especial, o Decreto $\mathrm{n}^{\circ} 19.770$ de 1931, o Decreto nº 24.694 de 1934 e a Constituição de 1934, criticando-as e discutindo as diferentes posturas do movimento operário frente a tais mudanças institucionais.

A pesquisa do período getulista que aqui se propõe compreende o lapso que vai de 1930 a 1935. Tal delimitação, no entanto, não é arbitrária. Em 1935, "o sindicalismo corporativo já estava implantado na maioria dos estados da Federação e nos maiores centros urbanos do país, sendo que neste as principais categorias de trabalhadores, muitas das quais com tradição anterior de luta e organização, já tinham substituído suas uniões e sindicatos autônomos por sindicatos oficiais". ${ }^{3}$ Além disso, esta é a data da ANL (Aliança Nacional Libertadora) e da intentona comunista e, é justamente em reação a estes movimentos que se termina por destruir por absoluto as organizações autônomas da classe operária, consolidando-se o sindicalismo corporativista.

desde a primeira Lei de Sindicalização (1931) até hoje, nem ignorar os importantes avanços conseguidos pelo novo sindicalismo e pela Constituição de 1988. Trata-se apenas de ressaltar a presença de alguns elementos invariáveis, com o intuito de mostrar a capacidade de resistência do sistema. Segundo Armando Boito Júnior tais aspectos são: 1) o princípio do sindicato único, que permite somente um sindicato por categoria em uma determinada unidade territorial, 2) o imposto sindical, uma dedução na folha de pagamento do salário de um dia de trabalho de todos os trabalhadores, sendo membros do sindicato ou não, 3) O reconhecimento oficial como um requisito para a existência do sindicato (BOITO JÚNIOR, A. O sindicalismo de Estado no Brasil. São Paulo: UNICAMP, 1991). Este último item deixou de viger após a Constituição Federal de 1988.

${ }^{3}$ CASTRO, Â. M. Estado e trabalhadores. In: ARAÚJO, Ângela Maria Carneiro [org.]. Do corporativismo ao neoliberalismo: estado e trabalhadores no Brasil e na Inglaterra. São Paulo: Boitempo, 2002. p. 53. 


\section{SINDICALISMO E REPÚBLICA VELHA}

A ordem jurídica que se institui no Brasil, no período republicano, é nitidamente liberal. As relações de trabalho devem ser reguladas exclusivamente pelo mercado. As tentativas de disciplinar seja pelo Estado, seja coletivamente, as condições de contratação dos assalariados eram vistas como atentatórias ao "livre exercício de qualquer profissão moral, intelectual e industrial" (CF de 1891, art. 72, § 24). A autonomia da vontade só poderia ser plenamente atingida com a pactuação individual e sem interferências externas, legitimada pela idéia de igualdade entre os contratantes. A questão social era remetida para o âmbito do Código Civil, através da disciplina da locação de serviços. Desta forma, "toda tentativa de corrigir, disciplinar ou regulamentar o mercado foi repelida em nome da liberdade de exercício profissional". 4

Porém, se a ordem liberal repele a possibilidade de qualquer tipo de intervenção sobre a mão invisível que regula o mercado, ela, contraditoriamente, através da liberdade de associação (CF de 1891, art. 72, §8º), cria as condições para sua própria superação. Isto é o que irá ocorrer com a incorporação no sistema jurídico de diplomas que regulam a atividade sindical. Porém, é preciso uma ressalva: "o movimento operário, embora legal, se inscreverá contraditoriamente num sistema de organização institucional que rejeita como ilegítimas as manifestações essenciais de sua existência" ${ }^{5}$. A repressão aos movimentos grevistas esteve presente em toda a República Velha, tendo preponderado na prática a visão do presidente Washington Rodrigues de que o problema social era caso de polícia.

Há, portanto, uma ambigüidade fundamental na ordem vigente. Ao mesmo tempo em que se nega qualquer interferência na auto-regulação do mercado, criam-se,

${ }^{4}$ (VIANNA, L. W. Liberalismo e sindicato no Brasil. Rio de Janeiro: Paz e Terra, 1976, p. 47). Luiz Werneck Vianna, ao contrário de outros autores que vêem o liberalismo brasileiro como um sinal da desadaptação de idéias, pensa que a ortodoxia liberal era extremamente funcional à ordem agrário exportadora deste período.

$$
{ }^{5} \text { Ibid., p. } 38
$$


através das Leis que permitem a organização sindical (Decreto $n^{\circ}$ 979, de 6 de janeiro de 1903 e Decreto $n^{0} 1.637$ de 5 de janeiro de 1907), condições para a atuação de um novo ente coletivo: o sindicato. O assalariado não mais atuará de forma individual, pois, "ao se permitir a organização sindical, faculta-se a viabilidade prática desse comparecer no mercado como categoria social". ${ }^{6}$ Assim, embora a ordem institucional não mais questione o direito de organização profissional através dos sindicatos, estes não podem exercer essa prerrogativa plenamente. No meio empresarial ainda vigora uma cultura individualista que se volta veementemente contra as tentativas de contratação coletiva das condições de trabalho. Além disso, o Estado estava sempre pronto a reprimir com seu poder de polícia as ações grevistas e a lutas por melhorias nas condições de trabalho. Se na ordem liberal o Estado não intervém na formação do contrato, que é realizada por indivíduos autônomos, "cabe a ele zelar pelo seu cumprimento [...], evitando que este seja rompido sem o mútuo consentimento das partes contratantes"7 . Porém, em situações de rompimento com o pactuado, como, por exemplo, em uma greve, cabe ao Estado intervir com seu poder de polícia para que as vontades livremente manifestadas nos diversos contratos individuais de trabalho, sejam restabelecidas. ${ }^{8}$.

O primeiro diploma a tratar da sindicalização no Brasil foi o Decreto-Lei $n^{0}$ 979 de 1903, que disciplinava a criação de sindicatos rurais. Segundo Edgar Carone a "sua organização tem mais espírito cooperativista do que de classe". 9 Isto realmente transparece quando se analisa algumas das faculdades atribuídas aos sindicatos: intermediação de créditos a favor dos sócios, aquisição de bens úteis ao exercício profissional dos sócios, venda de bens produzidos pelos sócios, organização de caixas rurais de crédito agrícola e de cooperativa de produção ou de consumo, de sociedade

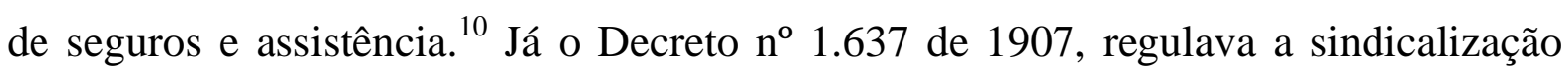

\footnotetext{
${ }^{6}$ Ibid., p. 50

${ }^{7}$ MUKANATA, K. A legislação trabalhista no Brasil. São Paulo: Brasiliense, 1981, p. 13

${ }^{8}$ Ibid., loc. cit.

${ }^{9}$ CARONE, E. A República velha: instituições de classes sociais. São Paulo: Difusão
} Européia do Livro, 1970, p. 244.

10 Segundo Evaristo de Morais Filho tal decreto teria sido promulgado atendendo "às 
urbana e também as sociedades cooperativas. Estabelecia o pluralismo sindical e ampla autonomia, bastando, para a regularização da entidade, o depósito em cartório dos atos constitutivos (art. $\left.2^{\circ}\right){ }^{11}$ No entanto, Boris Fausto atenta para um possível equívoco. "Apesar de consagrar a autonomia sindical, a Lei Tosta ${ }^{12}$ nada tinha a ver com o movimento operário autônomo da época. O projeto se inspirava em um pedido de corporações católicas do Nordeste, a cuja frente se encontrava a Federação Operária Cristã de Pernambuco, criada pelo industrial têxtil, Carlos Alberto de Menezes". ${ }^{13}$

A simples leitura dos textos legais referidos acima (Decreto 979 de 1903 e Decreto 1.637 de 1907) pode conduzir a interpretações equivocadas sobre o período analisado. Complementarmente à organização sindical liberal (pluralista e autônoma) tem-se a completa negação do direito de greve, ${ }^{14}$ a impossibilidade da negociação coletiva $^{15}$ e a constante intervenção policial sobre a movimentação operária. Não há, portanto, como compreender este período sem atentar para diversos diplomas legais que, embora não tratem diretamente do sindicalismo, tiveram um papel fundamental

solicitações constantes dos agricultores, formuladas em congressos, comícios, e conferência agrícolas" (MORAIS FILHO, E. O problema do sindicato único no Brasil. São Paulo: Alfa-Omega, 1978, p. 185).

${ }^{11}$ FAUSTO diz que aplicação desta lei "foi na prática muito restrita" (FAUSTO, B. Trabalho urbano e conflito social. 5. ed. Rio de Janeiro: Bertand Brasil, 2000, p. 224).

${ }^{12}$ (FAUSTO, op. cit., p. 224-225). Chama-se Lei Tosta, devido ao deputado baiano Joaquim Inácio Tosta, redator do projeto.

${ }^{13}$ Luis Werneck Vianna, ao contrário, dá a entender que a Lei de 1907 serviria como forma de institucionalizar as formas de organização sindical que a antecedem e que vinham desenvolvendo diversas lutas nos anos anteriores (VIANNA, op. cit., p. 34). Parece ser mais sensata a posição de Boris Fausto já que, apesar de consagrar a autonomia e pluralidade sindicais, o conteúdo da Lei Tosta era, em grande parte, marcado pelo mutualismo e pela assistência. Porém, independente do fato de ter sido o movimento operário autônomo o impulsionador da lei, o fato é que a partir de sua promulgação ele passará a utilizar-se da mesma, extrapolando, portanto, seu conteúdo assistencial inicial.

${ }^{14}$ CÓDIGO PENAL de 1890 - art. 205: "seduzir ou aliciar operários para deixarem os estabelecimentos em que forem empregados, sob promessa de recompensa ou ameaça de algum mal". Art. 206: "causar ou provocar cessação de trabalho, para impor aos operários ou patrões aumento ou diminuição de serviço ou salário". Segundo Boris Fausto o Decreto n ${ }^{\circ} 1.162$ de 1890 "resultou em modificações destes dispositivos [...]. A principal alteração consistiu em considerar crime a cessação do trabalho somente quando houvesse ameaças ou violências. A partir daí, Evaristo de Morais sustentou inutilmente que a greve pacífica passara a ser um direito reconhecido no país" (FAUSTO, op. cit., p. 234).

${ }^{15}$ Ambas as leis sindicais não faziam qualquer referência ao direito de negociação coletiva. 
em sua repressão.

O Decreto 1.641 de 1907 providencia a expulsão de estrangeiros do território nacional. Trata-se nitidamente de uma forma "de resposta aos surtos grevistas de 19061907". ${ }^{16}$ A onda de imigrantes, principalmente no caso dos anarco-sindicalistas italianos, passava a representar um ameaça ao status quo da República. Era preciso tornar ágil a expulsão dos elementos que praticassem atos "anti-sociais". O Decreto n ${ }^{o}$ 2.741 de 1913, mais conhecido como Lei Adolfo Gordo (pelo projeto ser de autoria de senador paulista de mesmo nome), consiste, na realidade, em uma intensificação da repressão à classe operária, que desenvolvia diversas lutas naquele momento. Revogam-se as garantias, ainda que parcas, presentes no Decreto $\mathrm{n}^{\circ} 1.651$ de 1907. Desta forma, elimina-se: a proibição de expulsão de estrangeiro que residir no território da República por dois anos contínuos, ou por menos tempo, quando casado com brasileira ou viúvo com filho brasileiro; e também, os mecanismos recursais contra as decisões de expulsão. ${ }^{17}$ Foram editados ainda outros decretos de conteúdo repressivo, todos com incidência direta sobre o movimento operário. O decreto n. 4.247, de 1921, que regula a entrada de estrangeiros no território nacional, ${ }^{18}$ o Decreto $\mathrm{n}^{\text {o }} 4.269$ de 1921, que regula a repressão ao anarquismo (segunda lei Adolfo Gordo) ${ }^{19}$

16 (FAUSTO, op. cit., p. 234). Para saber mais detalhes sobre o surto grevista vide (FAUSTO, op. cit., p. 133-153). Vide também, (CARONE, op. cit., p. 236).

17"O Supremo Tribunal Federal decretou a inconstitucionalidade da lei e as decisões judiciárias e portarias de expulsão voltaram a se referir ao texto de 1907. Entretanto seria ilusório pensar que esta lei relativamente benigna prevaleceu. Não só havia uma considerável distância entre o país real e o país legal, como ainda a própria Corte Suprema se encarregaria de dar a lei uma casuística interpretação, de acordo com as circunstâncias: assim, um julgado de outubro de 1917, em torno do rumoroso caso dos trabalhadores expulsos após a greve de julho, assentou que os anarquistas não podiam ser considerados residentes, pois constituíam um elemento flutuante, que vagava pelo país para propagar seus ideais e seus métodos" (FAUSTO, op. cit., p. 235)

${ }^{18}$ Prevê entre outras coisas: expulsão de estrangeiros nocivos à ordem pública e a segurança nacional, vedação de expulsão de estrangeiros que residirem no território nacional por mais de cinco anos ininterruptos. Neste último caso o estrangeiro deve provar: sua permanência em lugar ou lugares certos do território nacional durante aquele prazo; haver feito por termo, perante autoridade policial ou municipalidade dos lugares onde, no decurso desse tempo, residiu, ou para onde se mudou, a declaração de sua intenção de permanecer no país; manter ocupação habitual e lícita.

${ }^{19}$ Art. $1^{\text {o }}$ - Provocar diretamente, por escrito ou por qualquer outro meio de publicidade, ou verbalmente em reuniões realizadas nas ruas, teatros, clubes, sedes de associações, ou quaisquer lugares públicos ou franqueados ao público, a prática de crimes tais como dano, depredação, incêndio, homicídio, com o fim de subverter a atual organização social. Pena: prisão celular por um ano a quatro 


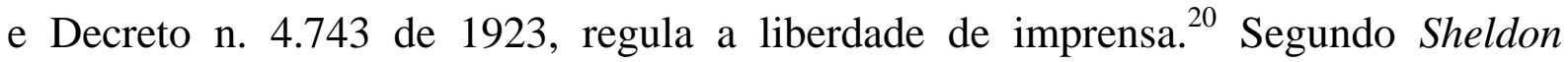
Maram,

depois da promulgação da lei de deportação de 1907, seis anos se destacaram com os maiores índices de deportados - 1907, 1913, 1917, 1919 e 1920. Precisamente nestes anos verificamos maior atividade operária no país. Além disso, um exame dos 71 indivíduos identificados como líderes estrangeiros nos mostrará que o Brasil abriu processos de deportação contra, no mínimo, 47 deles. Ainda mais reveladores são os dados sobre os 48 principais militantes estrangeiros envolvidos em atividades operárias no Brasil de 1917 à 1920, período mais ativo do movimento. Dos 48, o governo abriu processo contra 39 , ou seja, $81 \%{ }^{21}$

O resultado de toda essa repressão foi a latência vivida pelo movimento operário desde 1922, até o seu breve processo de reorganização nos primeiros anos da década de 1930. Foram anos marcados, sobretudo pelo estado de sítio (1922-1927) e pela conseqüente desmobilização.

A presença do conjunto legislativo acima aludido, bem como, de um aparato institucional construído com nítido intuito repressivo, mostram a preocupação do Estado e das elites dirigentes em conter os diversos surtos grevistas que marcaram as três primeiras décadas do século. Tal situação parece dar bons motivos para que a historiografia não incorpore, como algumas vezes o fez, o mito da outorga ${ }^{22}$ construído pelos bacharéis do período getulista. Ao contrário do que postulava Oliveira Vianna, que através de sua "psicologia social" descrevia os brasileiros como naturalmente

anos. Art. $2^{\circ}$ - Fazer pelos meios indicados no artigo antecedente, a apologia dos crimes praticados contra a atual organização social, ou fazer, pelos mesmos meios, o elogio dos autores desses crimes, com o intuito manifesto de instigar a prática de novos crimes da mesma natureza: Pena: prisão celular por seis meses a um ano.

${ }^{20}$ A indeterminação completa de alguns dispositivos como, por exemplo, a proibição de "ofensa à moral pública ou aos bons costumes, feita de qualquer modo pela imprensa" (art. $5^{\circ}$ ) abria espaço para as mais diversas arbitrariedades, inclusive contra a imprensa operária.

${ }^{21}$ MARAM, S. L. Anarquistas, imigrantes e o movimento operário. Rio de Janeiro: Paz e Terra, 1979, p. 45.

${ }^{22}$ Concepção segundo o qual as leis sociais editadas durante o período Vargas consistiam em mera liberalidade desse personagem caridoso, sem qualquer relação com a luta de classes. Tal visão foi compactuada por autores como Oliveira Vianna (VIANNA, O. Direito do trabalho e democracia social. Rio de Janeiro: José Olympio, 1945) e Cezarino Júnior (CEZARINO JÚNIOR. Direito social. São Paulo: LTr, 1980). 
apáticos e atomizados, carentes, portanto, de um Estado Corporativo capaz de construir laços de solidariedade social, ${ }^{23}$ o movimento operário possuía uma história de lutas de três décadas. No entanto, deve-se ter o cuidado de não afirmar a mentira através da negação da outorga. Se a experiência operária anterior à década de 30 pode ser considerada extremamente rica, não se pode descurar de suas limitações. Neste sentido, embora não se concorde completamente com o argumento de John D. French, que subestima a repressão aos sindicatos livres como forma de consolidar a nova estrutura sindical inaugurada com a Lei 19.770 de 1931, considera-se pertinente sua ressalva. Segundo ele, "naquela época, o poder de barganha dos operários urbanos variava muito de região para região dentro Brasil [...]. Mesmo nas regiões mais industrializadas, existiam também grande variações de ofício para ofício, com pequenos núcleos de força organizacional em diversas profissões - e uma organização relativamente eficaz em tipos específicos de ocupações em certos lugares". ${ }^{24}$

\section{TRANSIÇÃO PARA O SINDICALISMO CORPORATIVO}

Já no último decênio da República Velha, embora a questão social estivesse longe de deixar de ser caso de polícia, surgem algumas normas regulando questões trabalhistas. $^{25} \mathrm{O}$ crescimento do operariado urbano, sua dramática situação e seu potencial explosivo, já não podiam ser totalmente ignorados, o que não significa que tais leis foram realmente cumpridas. O importante é que, apesar de todas as limitações desta legislação, ela representava uma fenda na concepção liberal até então soberana

${ }^{23}$ VIANNA, O. Ensaios inéditos. Campinas: UNICAMP, 1991, p. 271.

${ }^{24}$ FRENCH, J. D. Afogados em leis: a CLT e a cultura política dos trabalhadores brasileiros. São Paulo: Perseu Abramo, 2001, p. 90-91.

${ }^{25}$ Decreto $^{\circ} 3550$ de 1918 (Institui as DNTs), Lei de Acidentes de Trabalho (Dec. no 3.724 de 1919), Lei Eloy Chaves (Decreto $n^{\circ} 4.682$ de 1923, que regula a caixa de aposentadorias e pensões para os ferroviários), Lei de Férias (Decreto $n^{\circ} 4.982$ de 1925), Código de Menores (Decreto $\mathrm{n}^{\circ} 5.086$ de 1926). Além disso, é importante recordar que, em 1919, o Brasil tornou-se signatário do Tratado de Versalhes que, entre outras medidas, criou a OIT (Organização Internacional do Trabalho). 
na regulação das relações de trabalho.

Em 1929, o discurso de Getúlio, em comício pela Aliança Liberal, dá uma idéia da importância que assume a classe trabalhadora para a disputa política nacional. Pela primeira vez, um candidato à presidência da República inclui, em sua plataforma eleitoral, uma pauta nitidamente operária. ${ }^{26}$ Após a Revolução, desde o início do governo provisório, iniciam-se diversas iniciativas na área laboral. Cria-se o Ministério do Trabalho, Indústria e Comércio ${ }^{27}$ (Ministério da Revolução), sob a direção do ministro Lindolfo Collor; o Departamento Nacional do Trabalho ${ }^{28}$ e a Lei de Sindicalização, ${ }^{29}$ a ser discutida mais adiante.

As palavras de Getúlio, ainda nos primeiros anos após a Revolução, dão algumas pistas para a interpretação do conjunto de medidas acima descritas.

O individualismo excessivo, que caracterizou o século passado, precisava encontrar limite e corretivo na preocupação predominante do interesse social. Não há nessa atitude nenhum indício de hostilidade ao capital, que, ao contrário, precisa ser atraído, amparado e garantido pelo poder público. Mas o melhor meio de garanti-lo está, justamente, em transformar o proletariado numa força orgânica de cooperação com o Estado e não o deixar, pelo abandono da lei, entregue à ação dissolvente de elementos pertubadores, destituídos dos sentimentos de Pátria e Família. ${ }^{30}$

Muito interessante é, também, a exposição de motivos da Lei de Sindicalização (Decreto 19.770), redigida por Lindolfo Collor:

26 "O manifesto da Aliança Liberal, divulgado em 20 de outubro de 1929, quando da instalação da Aliança Liberal, proclamava: 'A proteção aos interesses dos operários deve ser completa; a conquista das 8 horas, o aperfeiçoamento e ampliação da lei de férias, dos salários mínimos, a proteção das mulheres e dos menores, todo esse novo mundo moral que se levanta nos dias atuais em amparo ao proletariado deve ser contemplado pela nova legislação, para que não se continue a ofender os brios morais dos nossos trabalhadores com a alegação de que o problema social é um caso de polícia’ (SUSSEKIND. Curso de direito do trabalho. Rio de Janeiro: Renovar, 2002, p. 36).

\footnotetext{
${ }^{27}$ Decreto no 19.433 , de 26.11.1930.

${ }^{28}$ Decreto $^{\circ}{ }^{19.671-A}$ de 04.02 .31

${ }^{29}$ Lei 19.770 de 19.03.31.
}

${ }^{30}$ Vargas, G. A nova política do Brasil, vol. II, Rio de Janeiro, Livraria José Olympio, 1938, p. 97-98 apud ANTUNES, R. Classe operária, sindicatos e partido no Brasil: (um estudo sobre a consciência de classe: da Revolução de 30 até a Aliança Nacional Libertadora). São Paulo: Cortez, 1982, p. 74. 
Com a criação dos Sindicatos Profissionais moldados em regras uniformes e precisas, dá-se às aspirações dos trabalhadores e às necessidades dos patrões expressão legal, normal e autorizada. O arbítrio, tanto de uns como de outros, gera a desconfiança, é causa descontentamento, produz atritos que estalam em greves e lock-outs. Os sindicatos ou associações de classe serão os pára-choques dessas tendências antagônicas. ${ }^{31}$

São vários os aspectos comuns presentes em ambas as citações. Dentre eles, o repúdio ao liberalismo, apontado como impulsionador das agitações sociais, e uma visão corporativa, que prima pela concertação social orquestrada pelo Estado. Trata-se de elementos de um projeto autoritário-corporativo, gestado a partir década de 1920 por um grupo de intelectuais bacharéis, entre eles, Azevedo Amaral, Oliveira Vianna e Francisco Campos, e também por alguns extratos do movimento tenentista. Em linhas gerais, este grupo defendia, como solução para a crise das oligarquias agroexportadoras, um governo nacionalista, com centralização política, menor autonomia para os estados e municípios, o fim da representação parlamentar e sua substituição por um modelo de representação técnica, de tipo classista e um sindicalismo organizado nos moldes corporativos. ${ }^{32}$ Entretanto, embora se reconheça aqui algumas linhas gerais, é importante ressaltar a heterogeneidade das forças envolvidas na revolução de $30^{33}$ e os sucessivos rearranjos, avanços e recuos do projeto acima

${ }^{31}$ Louzada, A. J. Legislação social e trabalhista, DNT, 1933, p.402-403 apud ANTUNES, (op. cit, p. 76).

${ }^{32}$ CASTRO, op. cit., p. 34.

${ }^{33}$ Diversos autores, entre eles Ricardo Antunes, Luiz Werneck Vianna e Ângela Araújo, consideram a Revolução de 30 como uma "revolução pelo auto", ou, nos dizeres de Gramsci, uma revolução-restauração. Isto por ser um rearranjo no poder das elites dominantes. O protagonista deste processo, ao contrário do que poder-se-ia pensar em um primeiro momento, não foi a burguesia industrial. Neste período ela não tinha ainda capacidade política e econômica de organizar um novo projeto hegemônico capaz de contrapor-se à principal força política da República Velha, ou seja, à burguesia agro-exportadora. "A otimização dos interesses desse setor de classe [burguesia agroexportadora], dependendo do mundo exterior, implicava em uma política exclusivista que ignorava as reivindicações de outras facções burguesas e das camadas e estratos intermediários, no sentido de 'orientar para dentro' a política econômica do Estado" (VIANNA, L. W., op. cit., p. 133). É contra este exclusivismo que se voltam os principais atores vitoriosos em 30 (as oligarquias não ligadas à exportação do café, uma fração do movimento tenentista e as classes médias urbanas). Porém, não se trata apenas de uma troca de elites. "O movimento político militar de 1930, ao destruir a monopólio oligárquico do poder político, criou as condições institucionais indispensáveis à aceleração do processo de industrialização periférica (grifo do autor) e ao desabrochar de uma nova classe dominante. A revolução de trinta substitui o federalismo oligárquico, pela centralização políticoadministrativa e concede ao Estado os instrumentos institucionais indispensáveis à execução de uma política intervencionista e industrializante. Portanto, a burguesia industrial, mais que agente político 
esboçado. O risco da retomada do poder pelas oligarquias paulistas representado pela insurreição de São Paulo, em 1932, a composição das alianças governistas na Constituição de 1934, traziam para o jogo político elementos práticos diferentes dos esboçados naquela doutrina corporativista.

\section{A LEI DE SINDICALIZAÇÃO DE 1931}

Como já dito acima, o operariado brasileiro teve uma vasta experiência de luta nos primeiros decênios do século XX. Realizou diversas greves, organizou entidades autônomas, desenvolveu uma imprensa operária e, em certos casos (sindicatos de oficio anarquistas), chegou até mesmo a obter um alto controle sobre a oferta de trabalho em algumas atividades. Tais organizações, é certo, foram duramente reprimidas e, em muitos casos, destroçadas durante o governo Washington Rodrigues, porém, no período pós-revolução havia um nítido esforço de reconstrução. Portanto, a introdução de um novo modelo de sindicalismo, agora já sobre o controle estatal não foi uma tarefa fácil. A "resistência, que nos primeiros dois anos de vigência da lei sindical, de março de 1931, impediu o êxito da sindicalização oficial nos setores mais organizados do operariado, principalmente em São Paulo e em outros grandes centros urbanos, expressou-se na luta pela reorganização e fortalecimento de suas entidades autônomas e nos movimentos grevistas". ${ }^{34}$

O Decreto $\mathrm{n}^{\circ}$ 19.770, de 1931, estabelecia a unicidade sindical e a necessidade de reconhecimento do sindicato pelo Ministério do Trabalho, Indústria e Comércio. Iniciava o controle das atividades sindicais pelo Estado através do envio de regulares relatórios de acontecimentos sociais. Surgia a figura dos delegados sindicais do Ministério do Trabalho, a possibilidade de imposição de multas, destituição da

da revolução de trinta, foi sua criação (grifo do autor)" (ANTUNES, op. cit., p. 62).

${ }^{34}$ (ARAÚJO, op. cit., p. 47). Sobre essa resistência ver também (ANTUNES, op. cit., p. 82115; VIANNA, L. W., op. cit., p. 142-146; SILVA, Zélia Lopes da. A domesticação dos trabalhadores nos anos 30. São Paulo: Marco Zero, 1990, p. 95-106). 
diretoria e fechamento ou dissolução do sindicato pelo Ministério. Alçava-se o sindicato à condição de órgão de colaboração com o poder público e facultava-se, pela primeira vez, a realização de convenções e acordos coletivos, que deveriam ser posteriormente ratificados pelo Ministério do Trabalho. ${ }^{35}$

Como se vê, tal decreto representava uma verdadeira ameaça a ação direta dos chamados sindicatos livres, introduzia um regime tutelar em que a proposta dos trabalhadores de regulação do mercado de trabalho era substituída pela proposta dos burocratas ligados ao Ministério do Trabalho. Porém, a estratégia governamental não era, de forma alguma, baseada apenas na coerção. Foi através do binômio repressãoinclusão que se articulou o controle dos sindicatos. Pois, além de se usar a força do aparato policial para conter ações grevistas, ofertava-se também uma série de vantagens aos sindicatos oficiais, bem como aos seus filiados. São inúmeros os exemplos legislativos que marcam essa situação. Entre eles estão: a instituição de Comissões Mistas de Conciliação somente nas localidades onde existirem sindicatos ou associações profissionais (Decreto $n^{0} 21.396$ de 1932), organizados de acordo com a legislação vigente; direito de acionar as Juntas de Conciliação e Julgamento exclusivo aos empregados sindicalizados; a concessão de férias somente aos filiados ao sindicato (Decreto $\mathrm{n}^{\circ} 23.103$ de 1933). Além disso, as convenções coletivas possuíam, via de regra, aplicação somente entre as partes convenentes, estando previsto, no entanto, a ampliação dos seus efeitos por ato do Ministro do Trabalho. ${ }^{36}$

Tais "benefícios" dificultavam em grande medida a mobilização contra a Lei de Sindicalização. O exemplo emblemático disso é a atuação do Sindicato dos

${ }^{35}$ Apesar da opinião de Evaristo Morais Filho de que o controle estabelecido nesta lei era bem intencionado (MORAIS FILHO, op. cit., p. 221), tentando, assim, eliminar qualquer continuidade com relação à regulação sindical do Estado Novo, tal posição parece não ser a mais adequada. Os traços corporativos-autoritários deste diploma são bem nítidos e não destoam dos próximos decretos que regulam o tema. Ademais, o fato do decreto aproximar-se muito mais da legislação francesa do que da Carta del Lavoro, ou ainda, de seu próprio pai Evaristo de Morais, juntamente com Joaquim Pimenta, ambos notáveis socialistas da primeira república, terem contribuído na redação, não pode obscurecer suas arbitrariedades.

${ }^{36}$ A aplicação das convenções coletivas somente aos filiados ao sindicato permaneceu em todas as leis que tratavam do assunto durante a década de 1930 e acabou sendo incluída na redação original da CLT. Somente com o Decreto n ${ }^{\circ} 229$ de 1967 que os acordos e convenções passaram a ter efeitos erga omnes. 
Gráficos de São Paulo, liderado, no início da década de 1930, pelos trotskistas. Em um primeiro momento, tal sindicato procurou engajar-se simultaneamente em duas campanhas: contra a Lei de Sindicalização e pela universalização da Lei de Férias. Porém, sindicatos oficiais, com pouca ou nenhuma representatividade (os chamados sindicatos de "carimbo"), ou ainda, sem qualquer combatividade, acabavam garantindo as férias aos seus representados. Desta forma, a direção não possuía mínimas condições de justificar o esforço empreendido. O resultado final foi o pedido de reconhecimento ao Ministério do Trabalho, que só foi aceito após quase um ano. ${ }^{37}$

Assim, mesmo os setores à esquerda do movimento operário (comunistas e trotskistas), foram deixando de lado a luta contra a Lei de Sindicalização e passaram a disputar a direção dos sindicatos oficiais, buscando, a partir de dentro, garantir a autonomia dessas entidades. A avaliação exata dos resultados desta guinada é, sem dúvida, muito difícil. Porém, ela não foi isenta de consequiências. "Ela alterou a correlação de forças dentro do movimento sindical, favoravelmente ao sindicalismo corporativista, na medida em que representou um abandono dos sindicatos livres". ${ }^{38}$

Não se deve esquecer, no entanto, dos setores que apoiaram a Lei de Sindicalização e impulsionaram, desde o início, a oficialização dos sindicatos de que faziam parte. Trata-se, principalmente, dos chamados sindicalistas "amarelos". ${ }^{39}$ Estes tinham grande peso desde a República Velha nos sindicatos do Distrito Federal, principalmente, marítimos, portuários e ferroviários. Apesar de sua grande heterogeneidade possuíam alguns pontos em comum. Possuíam posições reformistas,

\footnotetext{
${ }^{37}$ MUNAKATA, op. cit., p. 88 à 94

${ }^{38}$ ARAÚJO, op. cit., p. 51
}

39 Essa denominação largamente incorporada pelo historiadores não deixa de ser problemática. É que ela reflete a posição dos anarquistas acerca de outras correntes sindicais da República Velha. Segundo tal perspectiva "foram os anarquistas que detiveram o monopólio de um proposta revolucionária de ação coletiva para a classe trabalhadora, surgindo como uma liderança heróica, pura e verdadeira. Desta forma, todas as demais propostas de auto-reconhecimento e organização dos trabalhadores ou desaparecem quase que completamente ou são encaradas como 'amarelas', 'reformistas', isto é, espúrias porque propagadas por elementos que se ligavam aos interesses do patronato ou do governo" (GOMES, A. de C. A invenção do trabalhismo. 2. ed. Rio de Janeiro: Relume-Dumará, 1994, p. 66). Portanto, o uso do termo "amarelo" só pode ser feito com as devidas ressalvas e apontando-se para a necessidade imperiosa de estudos sobre o sindicalismo na República Velha que busquem analisar com a devida atenção outras tradições organizativas. 
clamavam por soluções institucionais para as questões envolvendo as relações de trabalho, lutavam pela implementação de uma legislação social. Tais posições estavam, na época, muito próximas da proposta corporativa, o que tornava os "amarelos" uma importante base de apoio para a consolidação da nova legislação sindical. $^{40}$

Até 1935, o sindicalismo oficial estaria implementado na maioria dos estados da federação. Nesta data, as categorias mais importantes já haviam abandonado os antigos sindicatos livres. No entanto, tal processo não foi totalmente linear, pois, no período constitucional houve, conforme atesta Luiz Werneck Vianna, certa retomada dos ímpetos autonomistas, que foram finalmente eliminados com a derrota da ANL.

\section{A CONSTITUIÇÃO DE 1934 E O DECRETO 24.694}

O artigo 20 da Carta Constitucional de 1934 dispõe que: "Os sindicatos e as associações profissionais serão reconhecidos de conformidade com a lei". E o parágrafo único continua: "A lei assegurará a pluralidade sindical e a completa autonomia dos sindicatos". Em uma primeira leitura pareceria quase incompreensível que apenas três anos após a edição de uma Lei de Sindicalização, de caráter nitidamente corporativo, se promulgasse uma Constituição tão liberal em termos sindicais. Ou ainda, que uma sociedade madura, capaz de conceber um modelo de organização sindical tão avançado, fosse, após três anos, submetida sem insurgir-se ao regime autoritário do Estado Novo. Porém, através da análise das diversas forças políticas que compunham a Assembléia Constituinte e das diferentes posições em torno do modelo de organização sindical, pode-se inferir que as forças liberais eram minoritárias e que o papel da bancada ligada à Igreja Católica foi fundamental na

\footnotetext{
${ }^{40}$ Ibid., loc. cit.
} 
aprovação da pluralidade. ${ }^{41}$

\begin{abstract}
Nem empresários e nem operários, os atores por excelência do mundo liberal, preconizaram a inovação. Os primeiros concordavam com a fórmula do anteprojeto elaborado pela comissão designada pelo governo, que confirmava o disposto no Decreto $\mathrm{n}^{\circ}$ 19.770, de 1931. Os segundos temiam tanto o controle estatal quanto a pluralidade sindical. A pluralidade decorrerá da iniciativa da extensa bancada católica, associada aos juristas da primeira Carta republicana, representativos, em sua maioria, dos interesses da oligarquia agro-exportadora. No caso destes últimos, a nova institucionalização dos sindicatos se fazia congruente com sua orientação política e valores sociais. Interessava-lhes emancipá-los do Estado para diminuir a soma de poderes detida por este, ao mesmo tempo em que o pluralismo se afirmava melhor com seu passado liberal do que as proposições estatistas e as autenticamente classistas. ${ }^{42}$
\end{abstract}

Ao contrário do que se poderia imaginar, a bancada que representava os sindicatos e que se articulou na chamada Comissão dos 26, integrada também pelos comunistas, não apoiava a proposta pluralista. Para estes, a pluralidade era uma forma de pulverizar a representação sindical e era perfeitamente possível compatibilizar unicidade e autonomia. Portanto, resta a tentativa de compreensão da posição da bancada católica.

A posição da Igreja, refletida nos parlamentares católicos, não era de forma alguma uma opção política pelo liberalismo, mas sim uma opção tática. Já no século XIX, a encíclica papal Rerum Novarum criticava o caráter destrutivo do liberalismo que, marcado pela ganância incessante do lucro, era o principal culpado pelo surgimento do comunismo. Como solução para uma sociedade na qual se acirrava cada vez mais o conflito entre as classes, a Encíclica propunha menos cobiça por parte da burguesia e mais direitos sociais conferidos aos operários. Através da colaboração cristã entre todos os seres, proprietários e não proprietários se atingiria os desejos divinos. A Igreja, neste sentido, surgia como protagonista primordial de uma nova

${ }^{41}$ Este argumento é desenvolvido por Luiz Werneck Vianna (VIANNA, L. W., op. cit., p. 155-172). Evaristo de Morais Filho também ressalta o empenho da bancada católica na aprovação da pluralidade: "Queremos nos referir à influência católica que lutava ardentemente pela implantação da pluralidade sindical entre nós. Todos os seus líderes e intelectuais se expressavam a favor da pluralidade, em livros doutrinários, em manifestos, em conferências, em circulares, em mensagens aos Poderes Públicos" (MORAIS FILHO, op. cit., p. 236).

${ }^{42}$ VIANNA, L. W., op. cit., p. 155. 
ordem corporativa e antiliberal. Porém, a partir do segundo decênio do século XX, com a vitória fascista na Itália, a ordem corporativa laica proposta por Mussolini tornase uma verdadeira ameaça à Igreja. Ao incorporar completamente a sociedade civil ao Estado ela elimina a possibilidade da Igreja, através da construção de organizações políticas próprias (partidos, sindicatos e organizações de juventude), articular um projeto de hegemonia católico.

Esta posição tática parece ter amparo nos discursos proferidos pelos constituintes católicos. É o que se percebe analisando a fala do deputado Luis Sicupira. Este declara-se contra a liberal democracia, considerando-a como causadora de todos os males da civilização e propugna a construção de um "estado corporativo em que as corporações se manifestem, em que os grupos aparecerão, a família se reabilitará, a economia surgirá, e a Igreja igualmente se manifestará, a Igreja que é o pensamento moderno a dirigir e a inspirar como sempre os estados novos, que sem ela nada realizam". 43

Diante de tais circunstâncias, considera-se que a vitória do pluralismo na Constituinte de 1934 foi menos o resultado de uma grande representatividade liberal e mais uma opção tática da Igreja Católica, apoiada por setores da oligarquia agrária. A unicidade, naquele momento, inviabilizava a constituição de sindicatos católicos, o que significava um grande revés para qualquer objetivo de conquista de hegemonia.

Porém, a reação aos encaminhamentos da constituinte não tardaria. "Quatro dias antes de ser promulgada a Constituição, o Estado dá a sua resposta ao regime sindical dos constituintes. O Decreto $\mathrm{n}^{\circ} 24.694$ de 1934, em claro desrespeito à Assembléia Constituinte, ratifica o sistema tutelar. A autonomia sindical, conquistada contra a vontade do Estado, não terá força para se impor em um ordem inclusiva que a nega". 44

Tal decreto mantinha, na maioria dos aspectos, o sistema da Lei de Sindicalização e avançava no controle do Estado sobre os sindicatos. Os requisitos de

\footnotetext{
${ }^{43}$ Anais do Congresso Nacional de 1934, vol. XIII apud VIANNA, L. W., op. cit., p. 191.

${ }^{44}$ VIANNA, L. W., op. cit., p. 197.
} 
constituição e funcionamento dos sindicatos eram cada vez mais esmiuçados, sobrando pouco ou nenhum espaço para a autonomia. É o que se depreende, por exemplo, das condições para o reconhecimento do sindicato. Segundo o art. $8^{\circ}$, o pedido de reconhecimento de qualquer sindicato deverá ser acompanhado de cópia da ata da instalação, da relação copiada do livro de registo dos associados e dos respectivos estatutos, autenticados, todos pela mesa que houver presidido a sessão de instalação. Os estatutos deverão estabelecer: a sede e os fins do sindicato; as condições para admissão, exclusão e readmissão de sócios; os direitos e deveres dos associados; o processo de escolha, as atribuições e os casos de perda de mandato dos administradores; as condições em que se deverá extinguir o sindicato; o processo da substituição provisória dos administradores destituídos; o modo da constituição e administração do patrimônio social e o destino que lhe será dado, em caso de dissolução do sindicato. Além disso, só entrarão em vigor depois de aprovados pelo Ministério do Trabalho, Indústria e Comércio.

Quanto à pluralidade, apesar de teoricamente possível, era praticamente inviável. Para constituir-se o sindicato precisava de uma representatividade de "um terço dos empregados que exerçam a mesma profissão na respectiva localidade" (art. 5, II, a). Dessa forma, pode-se imaginar em uma situação ideal, na qual todos os empregados sejam sindicalizados, a hipótese de três sindicatos, cada um representando um terço do total de empregados. Porém, segundo Evaristo de Morais Filho "nunca tivemos, a rigor, uma pluralidade sindical em nossa história associativa depois de $1930 " .45$

Apesar do controle minucioso e de impossibilitar faticamente a pluralidade, o Supremo Tribunal Federal acabou admitindo a constitucionalidade do Decreto n. 24.694. ${ }^{46}$ Porém, segundo Luiz Werneck Vianna, as prolongadas discussões sobre o tema, até que se assentasse uma posição definitiva, provocaram um uma "folga" institucional que acabou dando um breve sopro de vida ao sindicalismo autônomo. Tal

\footnotetext{
${ }^{45}$ MORAIS FILHO, op. cit., p. 227.

${ }^{46}$ Sobre a discussão em torno da constitucionalidade ou não do Decreto no 24.694 de 1934 vide (MORAIS FILHO, op. cit., p. 233-236).
} 
situação estava expressa na ambigüidade das posições dentro do próprio ministério do trabalho. Oscar Saraiva, então procurador do Departamento Nacional do Trabalho, manifestava-se em um parecer acerca da requisição de anulação das eleições na União dos Empregados no Comércio do Rio de Janeiro, da seguinte forma: "Portanto, e tendo-se em vista os termos do preceito constitucional invocado, caberá tão somente à autoridade administrativa verificar se um sindicato possui as condições legais impostas ao seu reconhecimento como tal. Uma vez reconhecida a associação, sua vida se processará com inteira autonomia, independente de qualquer intervenção administrativa". 47 Dessa forma, o Ministério do Trabalho mostrava-se incapaz de conter as correntes autonomistas dentro de seu próprio corpo burocrático. ${ }^{48}$

Neste vácuo, que abalava até os membros do governo, cresce o sindicalismo autônomo, que atua nas eleições de 34, em São Paulo, com uma coligação operária, submetendo um programa mínimo aos candidatos que pleiteiam o voto da classe. Em 1935, a Aliança Nacional Libertadora, sob a liderança dos comunistas, realiza a Convenção Nacional de Unidade dos Trabalhadores, sendo fundada, nesta ocasião, a Confederação Unitária do Brasil. ${ }^{49}$

Apenas cinco dias após o primeiro comício da ANL promulga-se a chamada Lei Monstro (Lei n 38 de 1935 - Lei de Segurança Nacional). A partir de então a simples percepção de que a sociedade era dividida em classes sociais seria considerado crime (art. 14). O Decreto-Legislativo $n^{\circ} 6$ - de 18 de dezembro de 35 - emenda a Constituição com o fim de equiparar ao estado de guerra as comoções intestinas graves. Tais medidas representaram a eliminação total da autonomia sindical, com a sobrevivência apenas do sindicalismo corporativo. Com o acirramento dos conflitos de classe e o medo da sublevação operária, as forças políticas liberais e a Igreja Católica acabaram por endossar o projeto político corporativo-autoritário de Getúlio.

${ }^{47}$ Boletim do M.T.I.C, no 1 , de setembro de 1934 apud (MORAIS FILHO, op. cit., p. 233).

${ }^{48}$ VIANNA, L. W., op. cit., p. 199.

${ }^{49}$ Sobre o retomado do movimento operário entre 34 e 35 e sobre a Aliança Nacional Libertadora vide (ANTUNES, op. cit., p. 161-166; CARONE, E. O movimento operário no Brasil (1877- 1944). São Paulo: Difel, 1979, p. 549-558). 
Fechados os sindicatos autônomos, presas as suas lideranças, ampliado o consenso antiliberal, de 1935 a 1937 o Estado Novo aguarda apenas o momento da sua consagração constitucional, constituindo-se numa realidade de fato, a partir da desmobilização pela violência das classes subalternas e sua inclusão no interior da ordem corporativa. ${ }^{50}$

\section{CONCLUSÃO}

A impressão mais difundida acerca do primeiro governo Vargas dá a idéia de um líder carismático, de índole populista e, portanto, capaz de um contato direto com as massas. Trata-se da figura paterna (o pai dos pobres), ovacionado pela classe trabalhadora a quem concedeu apenas por liberalidade uma gama imensa de direitos sociais. Porém, este aparato ideológico, consubstanciado na idéia de outorga não nasceu acabado, mas foi construído. O mesmo ocorreu com a estrutura sindical corporativa. Para que esta pudesse se impor, tornar-se aceitável, foi necessária a utilização de diversos expedientes. Não se tratou somente de repressão, pois, como foi visto aqui, havia entre o movimento operário setores (sindicalismo amarelo) que aderiram espontaneamente. Mas foi também, e isso não pode ser ocultado, repressão. Foi preciso aniquilar, não só fisicamente, mas também simbolicamente os sindicatos livres, pois, além de destruídos eles haviam perdido o direito de ter história. As opções, entretanto, estiveram longe de se resumir à oposição entre livre adesão e repressão. O controle dava-se através desse jogo complexo entre positividade (garantia de direitos sociais) e negatividade (tutela estatal), consolidando o que se pode denominar "inclusão subordinada". Só no inicio da década de 40, com as campanhas de sindicalização em massa, com a instituição do imposto sindical e com a consolidação de um aparato propagandístico do governo, que os sindicatos passarão a constituir uma espécie de "reserva de mobilização" de apoio a Vargas. São, portanto, momentos distintos, que se confundidos levam a equivocada conclusão de que o populismo articula-se só através do carisma, ocultando-se o período repressivo que o antecedeu.

\footnotetext{
${ }^{50}$ VIANNA, L. W., op. cit., p. 203.
} 


\section{REFERÊNCIAS}

ANTUNES, R. Classe operária, sindicatos e partido no Brasil: (um estudo sobre a consciência de classe: da Revolução de 30 até a Aliança Nacional Libertadora). São Paulo: Cortez, 1982.

BOITO JÚNIOR, A. O sindicalismo de Estado no Brasil. São Paulo: UNICAMP, 1991.

CARONE, E. A República velha: instituições de classes sociais. São Paulo: Difusão Européia do Livro, 1970.

. O movimento operário no Brasil (1877- 1944). São Paulo: Difel, 1979.

CASTRO, Â. M. Estado e trabalhadores. In: ARAÚJO, Ângela Maria Carneiro [org.]. Do corporativismo ao neoliberalismo: estado e trabalhadores no Brasil e na Inglaterra. São Paulo: Boitempo, 2002.

CEZARINO JÚNIOR. Direito social. São Paulo: LTr, 1980.

FAUSTO, B. Trabalho urbano e conflito social. 5. ed. Rio de Janeiro: Bertand Brasil, 2000.

FRENCH, J. D. Afogados em leis: a CLT e a cultura política dos trabalhadores brasileiros. São Paulo: Perseu Abramo, 2001.

GOMES, A. de C. A invenção do trabalhismo. 2. ed. Rio de Janeiro: Relume-Dumará, 1994.

MARAM, S. L. Anarquistas, imigrantes e o movimento operário. Rio de Janeiro: Paz e Terra, 1979.

MORAES FILHO, E. O sindicato único no Brasil. Rio de Janeiro: A noite, 1952. O problema do sindicato único no Brasil. São Paulo: Alfa-Omega, 1978.

MUKANATA, K. A legislação trabalhista no Brasil. São Paulo: Brasiliense, 1981.

OLIVEIRA, F. Crítica à razão dualista. São Paulo: Boitempo, 2003.

PINHEIRO, P. S.; HALL, M. M. H. A classe operária no Brasil (1889 - 1830): documentos. São Paulo: Alfa Omega, 1979. v. 1: o movimento operário.

- A classe Operária no Brasil: (condições de vida e de trabalho, relações com os empresários e o Estado). São Paulo, Brasiliense, 1982.

RODRIGUES, J. A. Sindicato e desenvolvimento no Brasil. São Paulo: [s.e.], 1968. 
SILVA, Zélia Lopes da. A domesticação dos trabalhadores nos anos 30. São Paulo: Marco Zero, 1990.

SUSSEKIND. Curso de direito do trabalho. Rio de Janeiro: Renovar, 2002.

VIANNA, L. W. Liberalismo e sindicato no Brasil. Rio de Janeiro: Paz e Terra, 1976.

VIANNA, O. Direito do trabalho e democracia social. Rio de Janeiro: José Olympio, 1945.

. Ensaios inéditos. Campinas: UNICAMP, 1991. 